\title{
PREVALENCE OF THYROID DYSFUNCTION AMONG ANTENATAL WOMEN IN A TEACHING HOSPITAL
}

\author{
Matangi Ananda Kumari'1, Kodali Venkataramana², Kotipalli Padma Leela 3 , Sayeeda Aafreen ${ }^{4}$, Amrin ${ }^{5}$ \\ ${ }^{1}$ Assistant Professor, Department of Obstetrics and Gynaecology, Andhra Medical College, Visakhapatnam, Andhra Pradesh. \\ ${ }_{2}^{2}$ Assistant Professor, Department of Obstetrics and Gynaecology, Andhra Medical College, Visakhapatnam, Andhra Pradesh. \\ 3 Professor, Department of Obstetrics and Gynaecology, Andhra Medical College, Visakhapatnam, Andhra Pradesh. \\ ${ }^{4}$ Postgraduate Student, (DGO), Andhra Medical College, Visakhapatnam, Andhra Pradesh. \\ 5Postgraduate Student, Andhra Medical College, Visakhapatnam, Andhra Pradesh.
}

\begin{tabular}{l}
\hline ABSTRACT \\
BACKGROUND \\
Thyroid disorders in pregnancy can affect the health of the mother and child, before and after delivery leading to adverse maternal \\
and foetal outcome. The aim of the study is to study the prevalence of thyroid dysfunction in antenatal women attending teaching \\
hospital, Government Victoria Hospital, Andhra Medical College, Visakhapatnam.
\end{tabular}

\section{MATERIALS AND METHODS}

Thyroid function tests, i.e. serum TSH along with the other tests were done in all antenatal women attending OPD at fir st antenatal visit and those with abnormal TSH were subjected to serum T3 and T4 levels. Data was collected, and results were analysed. Sample Size- 4701.

Study Design- This is a prospective observational study that includes pregnant women attending Outpatient Department of Government Victoria Hospital for a period of one year from March 2016 to February 2017.

\section{RESULTS}

A total of 4701 pregnant women were tested for thyroid function tests. Results showed 18.9\% incidence of Hypothyroidism, of which $12.10 \%$ were Subclinical Hypothyroidism and $6.62 \%$ being Overt Hypothyroidism and $0.17 \%$ were Overt Hyperthyroidism.

\section{CONCLUSION}

Prevalence of Hypothyroidism in pregnant women was found to be high; majority being Subclinical Hypothyroidism in our study.

\section{KEYWORDS}

Antenatal Women, Thyroid Function Tests, Subclinical Hypothyroidism, Hyperthyroidism.

HOW TO CITE THIS ARTICLE: Kumari MA, Venkataramana K, Leela KP, et al. Prevalence of thyroid dysfunction among antenatal women in a teaching hospital. J. Evolution Med. Dent. Sci. 2018;7(04):441-444, DOI: 10.14260/jemds/2018/98

\section{BACKGROUND}

Thyroid disorders in pregnancy can affect the health of the mother and child before and after delivery. The deleterious effects of thyroid can affect the neuro-intellectual development in the early life of the child. Normal pregnancy is associated with significant changes in maternal thyroid physiology, which are reversible. Normally, iodine requirement and production of thyroid hormones increase by about 50\% during pregnancy.[1] Pregnancy is associated with increased urinary loss of iodine due to increased glomerular filtration rate, thus leading to iodine deficiency and maternal thyromegaly. The elevation of Human Chorionic Gonadotropin in pregnancy functions as a stimulator of TSH receptors. The alpha component of HCG being similar to TSH causes partial TSH suppression, thus causing a decline in TSH levels, more so during $1^{\text {st }}$ trimester. The thyroxine-binding globulin (TBG) is increased during pregnancy due to elevated oestrogen, resulting in hypothyroidism in women with limited thyroidal reserve or iodine deficiency.[2]

'Financial or Other Competing Interest': None.

Submission 06-12-2017, Peer Review 06-01-2018,

Acceptance 13-01-2018, Published 22-01-2018.

Corresponding Author:

Dr. Kotipalli Padma Leela,

Professor of OBG, Flat No. 304,

H. No. 18-1-21/10,

Vishnu Surya Prabha Paradise, Maharanipeta, Visakhapatnam.

E-mail: drkpadmaleela@gmail.com

DOI: $10.14260 /$ jemds $/ 2018 / 98$

\section{(c) $(1) \subseteq$}

Because of non-specific symptoms and hypermetabolic state of pregnancy, thyroid dysfunction may be overlooked and the diagnosis of thyroid disorders is exclusively biochemical.[3]

\section{Hyperthyroidism}

Is defined as Serum TSH level below the trimester specific reference range with elevated levels of Free T3, Free T4 or both and occurs in $0.1 \%$ to $0.4 \%$ of pregnancies.[4] Pregnant women with overt hyperthyroidism are at increased risk of spontaneous miscarriage, congestive heart failure, thyroid storm, preterm birth, preeclampsia, foetal growth restriction and increased perinatal mortality and morbidity.

\section{Overt Hypothyroidism}

Is defined as an elevated TSH level with a decreased level of Free T4 or TSH $>10 \mathrm{mIU} / \mathrm{L}$ irrespective of their Free T4 levels and around $0.5 \%$ of pregnant women will have overt hypothyroidism. The maternal effects of hypothyroidism are spontaneous or threatened abortion, preeclampsia, placental abruption and preterm delivery. The foetal and neonatal effects are foetal growth restriction, low birth weight, neonatal hyperbilirubinaemia, neonatal hypo/ hyperthyroidism, high perinatal mortality and low IQ levels in the child.

\section{Subclinical Hypothyroidism}

Is the most common thyroid disorder during pregnancy. It is defined as an elevated TSH levels between 2.5 and $10 \mathrm{mIU} / \mathrm{L}$ 
with a normal level of circulating free T4. Maternal subclinical hypothyroidism during early pregnancy has been shown to be associated with impaired neuropsychological development of children, preterm birth, preeclampsia, breech delivery and increased foetal mortality.

Since thyroid dysfunction adversely affects maternal and foetal outcome, present study was conducted to know the prevalence of thyroid dysfunction during pregnancy.

\section{Aim of the Study}

To study the prevalence of thyroid dysfunction in antenatal women attending the teaching hospital, Government Victoria Hospital, Andhra Medical College, Visakhapatnam, Andhra Pradesh, India.

\section{MATERIALS AND METHODS}

This hospital-based observational study was conducted at Government Victoria Hospital for Women and Children, Andhra Medical College, Visakhapatnam for a period of one year from March 2016 to February 2017. Serum TSH was done to all pregnant women who have attended Antenatal OPD along with other routine laboratory tests at first antenatal visit between March 2016 to February 2017 after taking history and clinical examination. If serum TSH was deranged, estimation of serum $\mathrm{T} 3$ and $\mathrm{T} 4$ was done. Trimester specific TSH normal ranges were used in the study based on the guidelines of American Thyroid Association 2011 and the following cut-offs were used to detect thyroid dysfunction. [5]

- First trimester: $0.1-2.5 \mathrm{mIU} / \mathrm{L}$.

- Second trimester: $0.2-3.0 \mathrm{mIU} / \mathrm{L}$

- Third trimester: $0.3-3.0 \mathrm{mIU} / \mathrm{L}$.

Based on results, patients were diagnosed as Euthyroid, Subclinical hypothyroidism, Overt Hypothyroidism and Overt Hyperthyroidism. A total of 4701 were evaluated for thyroid function tests. Thus, data was collected and results were analysed.

\section{Inclusion Criteria}

All primi gravidae and Multigravida irrespective of gestational age are included in the study.

\section{Exclusion Criteria}

A. H/O Diabetes Mellitus, Hypertension or other autoimmune disorders.

B. H/O thyroid dysfunction or thyroid surgery in the past.

\section{RESULTS}

In our study, a total of 4701 antenatal women were tested with Serum TSH and if abnormal TSH was found Serum T3 and $\mathrm{T} 4$ were done. According to the thyroid function tests out of 4701 cases were tested, 888 cases were diagnosed as having thyroid dysfunction, thus the incidence of thyroid dysfunction in pregnancy is $18.9 \%$.

\begin{tabular}{|c|c|c|c|c|}
\hline $\begin{array}{c}\text { Total No. } \\
\text { of } \\
\text { Cases }\end{array}$ & $\begin{array}{c}\text { Normal } \\
\text { Thyroid } \\
\text { Function }\end{array}$ & Percentage & $\begin{array}{c}\text { Abnormal } \\
\text { Thyroid } \\
\text { Function }\end{array}$ & Percentage \\
\hline 4701 & 3813 & $81.1 \%$ & 888 & $18.9 \%$ \\
\hline \multicolumn{5}{|c|}{ Table 1. Thyroid Function Tests } \\
\hline
\end{tabular}

Among the 888 cases with thyroid dysfunction, 880 cases were hypothyroid i.e. $18.7 \%$ of which 569 cases i.e. $12.10 \%$ were subclinical hypothyroidism and 311 cases i.e. 6.62\% showed overt hypothyroidism. Hyperthyroidism was found in 8 cases, the incidence of which was $0.17 \%$.

\begin{tabular}{|c|c|c|}
\hline Thyroid Dysfunction & No. of Cases & Percentage \\
\hline $\begin{array}{c}\text { Subclinical } \\
\text { hypothyroidism }\end{array}$ & 569 & $12.10 \%$ \\
\hline Overt hypothyroidism & 311 & $6.62 \%$ \\
\hline Overt hyperthyroidism & 8 & $0.17 \%$ \\
\hline \multicolumn{2}{|c|}{ Table 2. Thyroid Disorders [N= 888] } \\
\hline
\end{tabular}

Among 880 cases of hypothyroidism 569 cases, i.e. $12.10 \%$ were due to subclinical hypothyroidism and 311 cases i.e. $6.62 \%$ showed overt hypothyroidism. Thus, subclinical hypothyroidism predominated in our study. Only 8 cases, i.e. $0.17 \%$ were due to overt hyperthyroidism.

Age-Wise distribution of Women with Thyroid Dysfunction

\begin{tabular}{|c|c|c|c|c|}
\hline $\begin{array}{c}\text { Age Group } \\
\text { in Years }\end{array}$ & $\begin{array}{c}\text { No. of } \\
\text { Antenatal } \\
\text { Women } \\
\text { Tested }\end{array}$ & $\begin{array}{c}\text { No. of } \\
\text { Women } \\
\text { with } \\
\text { Normal } \\
\text { Thyroid } \\
\text { Function }\end{array}$ & $\begin{array}{c}\text { No. of } \\
\text { Women with } \\
\text { Abnormal } \\
\text { Thyroid } \\
\text { Function }\end{array}$ & \% \\
\hline $15-20$ yrs. & $672(14.3 \%)$ & 578 & 98 & $11 \%$ \\
\hline $21-25$ yrs. & $\begin{array}{c}2289 \\
(48.7 \%)\end{array}$ & 1823 & 471 & $53 \%$ \\
\hline $26-30$ yrs. & $\begin{array}{c}1288 \\
(27.4 \%)\end{array}$ & 1059 & 231 & $26 \%$ \\
\hline$>30$ yrs. & 452 & 353 & 88 & $10 \%$ \\
\hline Total & $\mathbf{4 7 0 1}$ & $\mathbf{3 8 1 3}$ & $\mathbf{8 8 8}$ & $\mathbf{1 0 0 \%}$ \\
\hline \multicolumn{7}{|c|}{ Table 3. Age-Wise Distribution } \\
\hline
\end{tabular}

In our study 98 women were between 15 - 20 yrs. of age with an incidence of $11 \%, 471$ were between $21-25 \mathrm{yrs}$. with an incidence of 53\%, 231 were between $26-30$ yrs. of age group with an incidence of $26 \%$ and 88 women were above 30 years of age with an incidence of $10 \%$. Thus, women with thyroid dysfunction predominated in the age group of 21 - 25 yrs. with an incidence of $53 \%$.

\section{Distribution of Thyroid Dysfunction as per Gravidity}

\begin{tabular}{|c|c|c|c|c|}
\hline Gravida & $\begin{array}{c}\text { No. of } \\
\text { Antenatal } \\
\text { Women } \\
\text { Tested }\end{array}$ & $\begin{array}{c}\text { No. } \\
\text { of Women } \\
\text { with Normal } \\
\text { Thyroid } \\
\text { Function }\end{array}$ & $\begin{array}{c}\text { No. of } \\
\text { Women } \\
\text { With } \\
\text { Abnormal } \\
\text { Thyroid } \\
\text { Function }\end{array}$ & $\%$ \\
\hline Primi & $2052(43 \%)$ & $1715(45 \%)$ & 337 & $38 \%$ \\
\hline G2 & $1058(22.5 \%)$ & $800(21 \%)$ & 258 & $29 \%$ \\
\hline G3 & $702(14.5 \%)$ & $533(14 \%)$ & 169 & $19 \%$ \\
\hline $\begin{array}{c}\text { G4 or } \\
\text { more }\end{array}$ & $889(19.1 \%)$ & $765(20 \%)$ & 124 & $14 \%$ \\
\hline Total & $\mathbf{4 7 0 1 ( 1 0 0 \% )}$ & $\mathbf{3 8 1 3}(\mathbf{1 0 0} \%)$ & $\mathbf{3 3 7}$ & $\mathbf{1 0 0 \%}$ \\
\hline \multicolumn{4}{|c|}{ Table 4. Gravida Wise Distribution } \\
\hline
\end{tabular}

In our study on analysing the obstetric history of women with thyroid dysfunction 337 women were primi gravidae with an incidence of $38 \%, 258$ women were G2 with an 
incidence of 29\%, 169 women were G3 with an incidence of $19 \%$, whereas 124 women were G4 and above with an incidence of $14 \%$. Thus, primi gravidae predominated in the study with an incidence of $38 \%$.

\begin{tabular}{|c|c|}
\hline Sahu et al, 2010, Hyderabad & $6.7 \%$ \\
\hline Dhanwal et al, 2013, North India & $14.3 \%$ \\
\hline PV Bhandela et al, 2013, Rayalaseema & $18.7 \%$ \\
\hline Jaiswal et al, 2016, Lucknow & $11 \%$ \\
\hline Nabhi Bhashya Karla, et al, 2014, Telangana & $26 \%$ \\
\hline Rajesh Rajput et al, 2015, Haryana & $21.5 \%$ \\
\hline Indira et al, 2017, Vizianagaram & $16.21 \%$ \\
\hline Our Study, 2017, Vishakhapatnam & $18.7 \%$ \\
\hline \multicolumn{2}{|c|}{$\begin{array}{c}\text { Table 5. Prevalence of Thyroid Dysfunction in Pregnancy } \\
\text { in Different Studies }\end{array}$} \\
\hline
\end{tabular}

\section{DISCUSSION}

Thyroid disorders in pregnancy are associated with adverse foetal and maternal outcome. There is a wide variation in prevalence of thyroid dysfunction in pregnancy all over the world. The Western studies report a prevalence of hypothyroidism in pregnancy as $2.5 \%$ and a prevalence of $0.1-0.4 \%$ of hyperthyroidism. Roberto Negro et al in BMJ $2014,[6]$ in their study reported the prevalence of undiagnosed subclinical hypothyroidism in pregnant women ranges from $3 \%$ - 15\%. The prevalence reports of hypothyroidism during pregnancy in India ranges from 4.8\%$11 \%$.

Our study has shown a prevalence of $18.7 \%$ of Hypothyroidism, of which $12.10 \%$ was Subclinical hypothyroidism and $6.62 \%$ showed Overt hypothyroidism. The incidence of Overt hyperthyroidism in our study is $0.17 \%$. The cut-off values of serum TSH in $1^{\text {st }}$ trimester were $2.5 \mathrm{mIU} / \mathrm{L}$ and in $2 \mathrm{nd}$ and $3^{\text {rd }}$ trimester was $3 \mathrm{mIU} / \mathrm{L}$ in our study. This high prevalence in our study has been attributed to the presence of goitrogens in the diet and deficiency of micronutrients like selenium and iron. Many Indian studies report high prevalence of thyroid disorders in pregnancy. Dhanwal et al from Delhi in 2013[7] reported a prevalence of $14.3 \%$ of hypothyroidism with a TSH cut-off of $4.5 \mathrm{mIU} / \mathrm{L}$ in his study. Jaiswal et al 2014 reported a prevalence of $18 \%$ hypothyroidism with a TSH cut-off of $2.5 \mathrm{mIU} / \mathrm{L}$; Nabhi and Bhashya Karla 2014,[8] reported a prevalence of $26 \%$ of hypothyroidism in their study with a TSH cut-off level of 3 mIU/L and with the same TSH cut-off Murthy et al reported an incidence of $19.4 \%$. Mandal et al 2016 has reported a prevalence of $32.94 \%$ of hypothyroidism with a TSH cut-off of $2.5 \mathrm{mIU} / \mathrm{L}$. In another study, Sahu et al[9] have done thyroid function tests in $2^{\text {nd }}$ trimester in high-risk pregnant women and reported a prevalence of $6.47 \%$ hypothyroidism. Study by Rajesh Rajput et al 2015[10] reported a high prevalence of thyroid disorders during pregnancy, i.e. $21.5 \%$ of Subclinical Hypothyroidism and $1.3 \%$ of Hypothyroidism and $0.4 \%$ of Overt Hypothyroidism. Thus, our study is comparable in prevalence of Hypothyroidism to that of Jaiswal et al [18\%] and Murthy et al [19.4\%]. The prevalence rate in our study is also comparable with the study of Pandit V Bandela et al[11] (18.7\%) done in Rayalaseema region of Andhra Pradesh and Indira et al in 2017. Wei Wang et al in 2010[12] reported in his study that the prevalence of hypothyroidism was significantly higher in the high-risk group than in the non-high risk group, 10.9 vs $7 \%$. The prevalence of hyperthyroidism was not significantly different from the high-risk and non-high risk group, 2.7 vs. $1.6 \%$.

In our study, thyroid dysfunction was the most common in women aged between 21 - 25 yrs. i.e. 53\% as shown in Table No. 3, which is comparable to study by Indira et al 2017[13] who reported highest incidence in the age group of 21 - 25 yrs. As shown in Table 4, our study had predominancy of primi gravidae. This is comparable to a study by Alpana Singh et al, who reported that most of the cases were primi gravidae.

Our study concludes that there is high prevalence of thyroid dysfunction in pregnancy in India, majority being subclinical hypothyroidism and hence universal screening of thyroid dysfunction is recommended in our country.

Limitation of the study is anti-thyroid antibodies were not assayed in our study.

\section{CONCLUSION}

Maternal thyroid dysfunction has a great potential to adversely affect maternal and foetal health leading to abnormal maternal and foetal outcome, particularly impaired neurological development of the foetus.

Thus, early detection of thyroid dysfunction in all antenatal women, prompt initiation of treatment and regular follow-up can reduce the adverse maternal and foetal outcome.

\section{ACKNOWLEDGEMENTS}

Authors wish to thank the participants of this study and the scholars whose articles are cited and included in the references of this manuscript. The authors are also grateful to authors, editors and publishers of all those articles, journals and books from where the literature of this article has been reviewed and discussed.

\section{REFERENCES}

[1] Thobbi VA, Majeed S. Prevalence of thyroid disorder in pregnancy. International Journal of Technical Research and Applications 2016;4(2):12-6.

[2] Singh A. Prevalence of thyroid dysfunction in pregnancy and its implications. Int J Med Sci Public Health 2015;4(9):1247-50.

[3] Thanuja PM, Rajgopal K, Sadiqunnisa. Thyroid dysfunction in pregnancy and its maternal outcome. IOSR Journal of Dental and Medical Sciences 2014;13(1):11-5.

[4] Chang DL, Pearce EN. Screening for maternal thyroid dysfunction in pregnancy: a review of clinical evidence and current guidelines. J Thyroid Res 2013;2013:851326.

[5] Rao S, Patibandla A. A study to find out the prevalence of hypothyroidism among pregnant women visiting ESI hospital, Sanath Nagar, Hyderabad. Gynecol Obstet 2016;6:363.

[6] Negro R. Diagnosis and management of subclinical hypothyroidism in pregnancy. BMJ 2014;349:4929.

[7] Dhanwal DK, Prasad S, Agarwal AK, et al. High prevalence of subclinical hypothyroidism during first trimester of pregnancy in North India. Indian J Endocrinol Metab 2013;17(2):281-4. 
[8] Nabhi VRM, Bhashyakarla U. Prevalence of thyroid dysfunction among pregnant women in a rural teaching hospital in Telangana, South India. Scholars Journal of Applied Medical Sciences 2014;2(6B): 2022-5.

[9] Sahu MT, Das V, Mittal S, et al. Overt and subclinical thyroid dysfunction among Indian pregnant women and its effect on maternal and fetal outcome. Arch Gynecol Obstet 2010;281(2):215-20.

[10] Rajput R, Goel V, Nanda S, et al. Prevalence of thyroid dysfunction among women during the $1^{\text {st }}$ trimester of pregnancy at a tertiary care hospital in Haryana. Indian J Endocrinol Metab 2015;19(3):416-9.
[11] Vinodh BP, Havilah P, Hindumathi M, et al. Antenatal thyroid dysfunction in Rayalseema region: a preliminary cross sectional study based on circulating serum thyrotropin levels. IJABPT 2013;4(4):74-8.

[12] Wang W, Teng W, Shan Z, et al. The prevalence of thyroid disorders during early pregnancy in China: the benefits of universal screening in the first trimester of pregnancy. Eur J Endocrinol 2011;164(2):263-8.

[13] Indira G, Rao TN, Premavardhini Y, et al. Prevalence of thyroid disorders in pregnancy at a teaching hospital. JEBMH 2017;4(2):64-70. 